\title{
Enamel crystals of mice susceptible or resistant to dental fluorosis: an AFM study
}

\author{
Marília Afonso Rabelo BUZALAF${ }^{1}$, Carolina Silveira BARBOSA ${ }^{1}$, Aline de Lima LEITE ${ }^{1,2}$, Sywe-Ren CHANG ${ }^{3}$, Jun \\ LIU $^{3}$, Agata CZAJKA-JAKUBOWSKA ${ }^{4}$, Brian CLARKSON ${ }^{4}$ \\ 1- Department of Biological Sciences, Bauru School of Dentistry, University of São Paulo, Bauru, SP, Brazil. \\ 2- Department of Genetics and Evolution, Center of Biological Sciences and Health, Federal University of São Carlos, São Carlos, SP, Brazil. \\ 3- Department of Cariology, Restorative Sciences and Endodontics, University of Michigan School of Dentistry, U.S.A. \\ 4- Department of Conservative Dentistry and Periodontics, Poznan University of Medical Sciences, Poland.
}

Corresponding address: Marília Afonso Rabelo Buzalaf - Departamento de Ciências Biológicas, Faculdade de Odontologia de Bauru, Universidade de São Paulo - Al. Dr. Octávio Pinheiro Brisola, 9-75 - Bauru-SP - 17012-901 - Brazil - Phone: + 551432358346 - Fax + 551432271486 - e-mail: mbuzalaf@fob.usp.br

Submitted: September 6, 2013 - Modification: January 21, 2014 - Accepted: January 22, 2014

\section{ABSTRACT}

\begin{abstract}
O bjective: This study aimed to assess the overall apatite crystals profile in the enamel matrix of mice susceptible (A/J strain) or resistant (129P3/J strain) to dental fluorosis through analyses by atomic force microscopy (AFM). Material and Methods: Samples from the enamel matrix in the early stages of secretion and maturation were obtained from the incisors of mice from both strains. All detectable traces of matrix protein were removed from the samples by a sequential extraction procedure. The purified crystals $(n=13$ per strain) were analyzed qualitatively in the AFM. Surface roughness profile (Ra) was measured. Results: The mean ( $\pm S D)$ Ra of the crystals of A/J strain $(0.58 \pm 0.15 \mathrm{~nm})$ was lower than the one found for the $129 \mathrm{P} 3 / \mathrm{J}$ strain $(0.66 \pm 0.21 \mathrm{~nm})$ but the difference did not reach statistical significance $(t=1.187, p=0.247)$. Crystals of the $129 \mathrm{P} 3 / \mathrm{J}$ strain $(70.42 \pm 6.79 \mathrm{~nm})$ were found to be significantly narrower $(t=4.013, p=0.0013)$ than the same parameter measured for the $A / J$ strain $(90.42 \pm 15.86 \mathrm{~nm})$. Conclusion: Enamel crystals of the 129P3/J strain are narrower, which is indicative of slower crystal growth and could interfere in the occurrence of dental fluorosis.
\end{abstract}

Keywords: Dental fluorosis. Genetic susceptibility. Fluorides. Atomic force microscopy.

\section{INTRODUCTION}

The widespread use of fluoride $(F)$ has contributed to a reduction in the prevalence and incidence of dental caries worldwide ${ }^{2}$. However, along with the decline of tooth decay, an increase in dental fluorosis has been observed, a side-effect resulting from exposure to $\mathrm{F}$ above the recommended levels during the period of tooth formation ${ }^{1}$. This increased prevalence of dental fluorosis has been observed throughout the world, both in fluoridated and in non-fluoridated areas ${ }^{7,12,24}$.

It is known that $\mathrm{F}$ interacts with mineralized tissues, and in high concentrations can harm the process of mineralization ${ }^{1}$. However, the molecular mechanisms involved in the pathogenesis of fluorosis are not completely understood ${ }^{3}$. Enamel formation is a complex process involving cell proliferation and differentiation through epithelial-mesenchymal sequential secretion of matrix proteins, tissuespecific transport of ions, including calcium and fluoride, and precipitation and alignment of the crystals of enamel through interactions between organic and inorganic molecules ${ }^{1}$.

Increases in the roughness of apatite crystals surfaces in developing fluorosed enamel have been reported $6,14,19$. It was suggested that these roughened crystals could cause fluorosis because they would impair crystal growth due to changes in crystal surface chemistry and/or incomplete removal of matrix proteins. These events are known to hinder crystal development ${ }^{1,19}$. Additionally, rougher crystals have been shown to bind increased amounts of protein in other tissues ${ }^{11}$. Several reasons related to the process of enamel development have been suggested for the increased roughness, such as deposition of less soluble fluoridated mineral species reflecting higher 
supersaturation level in tissue fluid and retention of matrix proteins due to their increased interaction with the altered crystal surface ${ }^{19,20}$. However, it was shown that increased roughness of enamel crystals could also be observed after in vitro treatments with $\mathrm{F}$ in solutions undersaturated with respect to apatite indicating that surface roughness should not originate directly from growth-related phenomena, but from restructuring of the crystal surface ${ }^{6}$.

Despite the cause-effect relationship between fluoride exposure and dental fluorosis is well established, other factors seem to account for the severity of dental fluorosis ${ }^{21}$. The observation that certain ethnic groups are more susceptible to this disease ${ }^{15,25}$ led some researchers to investigate the genetic susceptibility of different mice strains to dental fluorosis. It was observed that $A / J$ mice are highly susceptible to dental fluorosis, while 129P3/J mice are little affected ${ }^{8}$, despite retaining more $F$ in the body, which leads to higher femur and plasma $\mathrm{F}$ concentrations ${ }^{5}$. A recent study compared the profile of protein expression in kidney of $\mathrm{A} / \mathrm{J}$ and $129 \mathrm{P} 3 / \mathrm{J}$ mice. Key proteins that could possibly regulate metabolism of water and $F$ were identified $^{17}$.

An interesting observation was that the susceptible mice $(A / J)$ presents greater retention of proteins in the maturing enamel, even in the case of no exposure to fluoride 9 . This led us to the assumption that differences in the profile of the crystals surfaces, regardless exposure to $F$, would exist between $\mathrm{A} / \mathrm{J}$ and $129 \mathrm{P} 3 / \mathrm{J}$ mice strains and this could have an implication on the mechanisms of dental fluorosis development. It was observed that the length and width of bone crystals of the "resistant" 129P3/J strain mice was smaller than the same parameter for the $A / J$ strain ${ }^{17}$, suggesting that the crystal growth rate of the "resistant" strain is slower than that of the "susceptible" strain. However, differences in crystal dimensions between the strains were not evaluated yet for enamel. Slower crystal growth rate would allow for an appropriate buffering action of amelogenins that under the adequate $\mathrm{pH}$ would remain attached to the crystal surface, guiding its growth ${ }^{3}$. Thus, the aim of the present study was to assess the overall apatite crystal profile in the enamel mineral matrix of mice susceptible $(\mathrm{A} / \mathrm{J})$ or resistant $(129 \mathrm{P} 3 / \mathrm{J})$ to dental fluorosis through analyses by atomic force microscopy (AFM). It was primarily hypothesized that $A / J$ mice would have rougher and wider crystals when compared with 129P3/J mice, which would lead to higher retention of matrix proteins and this could help to explain their increased susceptibility to dental fluorosis.

\section{MATERIAL AND METHODS}

Mice

The protocol of this study was approved by the Ethics Committee for Animal Research of Bauru School of Dentistry, University of São Paulo (Proc. 026/2007).

Weanling (3-week-old) male $129 \mathrm{P} 3 / \mathrm{J}$ and $\mathrm{A} / \mathrm{J}$ mice (12 from each strain) were obtained from the Jackson Laboratory (Bar Harbor, ME, USA). The reason for the selection of these two strains is based on the fact that the strain $A / J$ is highly susceptible to dental fluorosis, with a rapid and severe development of the disease when the animal is exposed to $F$, while the strain $129 \mathrm{P} 3 /$ J is less affected, with a low rate of dental fluorosis ${ }^{8}$. In addition, the phenotypic and genetic differences among animals, and their general availability as standard laboratory strains, have also contributed to their selection.

Animals of the same strain were housed in plastic cages ( $n=6$ per cage) in the vivarium of Bauru School of Dentistry. The temperature and humidity in the climate-controlled room, which had a 12 -hour light/dark cycle, were $23 \pm 1^{\circ} \mathrm{C}$ and $40-80 \%$, respectively. The animals had free access to deionized water and a semi-purified diet with low $\mathrm{F}$ concentration (around $1 \mathrm{ppm}$ ) that was prepared in our laboratory.

\section{Euthanasia of animals and sample collection}

At the end of the experimental period (age 12 weeks), animals were anesthetized with ketamine and xylazine. The jaws were removed, the incisors extracted, carefully dissected, washed in cold 0.1 $\mathrm{M}$ phosphate buffer $(\mathrm{pH} 7.4)$ and allowed to dry for about $3 \mathrm{~min}$ at room temperature until an opaque area was visible. It was then possible to distinguish between the secretion and maturation phases of enamel formation ${ }^{4}$. With a scalpel, the enamel matrix in the early stages of secretion and maturation was scraped in pre-weighed and identified tubes of $1.5 \mathrm{~mL}$ until the enamel became too hard to be cut ${ }^{18}$.

\section{Isolation of the enamel crystals}

All detectable traces of matrix protein were removed from the enamel samples by a sequential extraction procedure previously described ${ }^{13}$. Briefly, the enamel particles were first extracted with $0.1 \mathrm{M}$ phosphate buffer, $\mathrm{pH} 7.4$, to desorb mineral bound and freely mobile species. The insoluble residue after extraction was pelleted by centrifugation and the supernatant removed. This was repeated for a total of 6 times. The pelleted material was then further extracted in $50 \mathrm{mM}$ TRIS containing $4 \mathrm{M}$ urea at $\mathrm{pH} 7.0$ to dissolve aggregated protein. This extraction was also repeated 6 times as described 
above. The insoluble residue was then reextracted for a further 6 times with $0.1 \mathrm{M}$ phosphate buffer, $\mathrm{pH}$ 7.4 , to ensure final desorption of any mineral-bound components. The final extraction used distilled water with the $\mathrm{pH}$ adjusted to 7.0 in order to remove all traces of buffer and urea. Centrifugation and ressuspension of the pellet was again repeated 6 times. Samples were dried in a desiccator for at least 3 hours.

Protein removal from the crystals was monitored by polyacrylamide gel electrophoresis of the extraction solutions and of crystals obtained in a pilot study. Part of the sample from each group was also gold-sputtered and analyzed by SEM to confirm the presence of enamel crystals.

The enamel crystals were sonicated for $40 \mathrm{~min}$ in HPLC-grade methanol to prevent aggregation. Approximately $10 \mu \mathrm{L}$ of this suspension were then placed onto freshly cleaved mica (mica discs PELCO ${ }^{\circledR}, 9 \mathrm{~mm}$ diameter, Ted Pella, Inc, CA, USA). The methanol evaporated rapidly leaving a spread of dispersed apatite crystals on the surface that would be subsequently examined by AFM.

\section{Atomic force microscopy}

Purified crystals from the mice incisors were imaged on a NanoScope IIIa Multimode AFM and controller (Digital Instruments, Santa Barbara, CA,
USA), equipped with a JV-type scanner ( 120x120 $\mu \mathrm{m}$ maximum scan range in $\mathrm{x}-\mathrm{y}$ direction). Tapping mode in air images were obtained using standard NSC15/AIBS silicon single-rectangular cantilever (MikroMasch, Tallinn, Estonia) of quoted spring constant $46 \mathrm{~N} / \mathrm{m}$, radii of curvature less than $10 \mathrm{~nm}$, thickness of 3.5-4.5 $\mu \mathrm{m}$, tip height of 20-25 $\mu \mathrm{m}$, cantilever length of $125 \mu \mathrm{m}$ and resonant frequency of $265-400 \mathrm{kHz}$. Cantilevers were resonated at approximately $100-500 \mathrm{kHz}$ with drive amplitude in the range $110-270 \mathrm{mV}$ and images obtained at tapping amplitude of approximately $80 \%$ of free amplitude. Multiple images for each sample were obtained with scan sizes ranging from $100 \times 100 \mathrm{~nm}$ to $1 \times 1 \mu \mathrm{m}$.

\section{Measurement of surface roughness}

Surface roughness measurement $\left(R_{a}\right)$ was obtained over a length of 30-80 $\mathrm{nm}$ in an approximately central line parallel to the crystal c-axis. Thirteen crystals from each group were analyzed $^{6}$. For each crystal, a minimum of 5 measurements were obtained in order to achieve a final mean roughness value for that crystal. $R_{a}$ roughness was calculated using a Nanoscope III 5.12r3 software and was defined as:

$$
R_{a}=\frac{1}{L} \int_{0}^{L}|f(x)| d x
$$
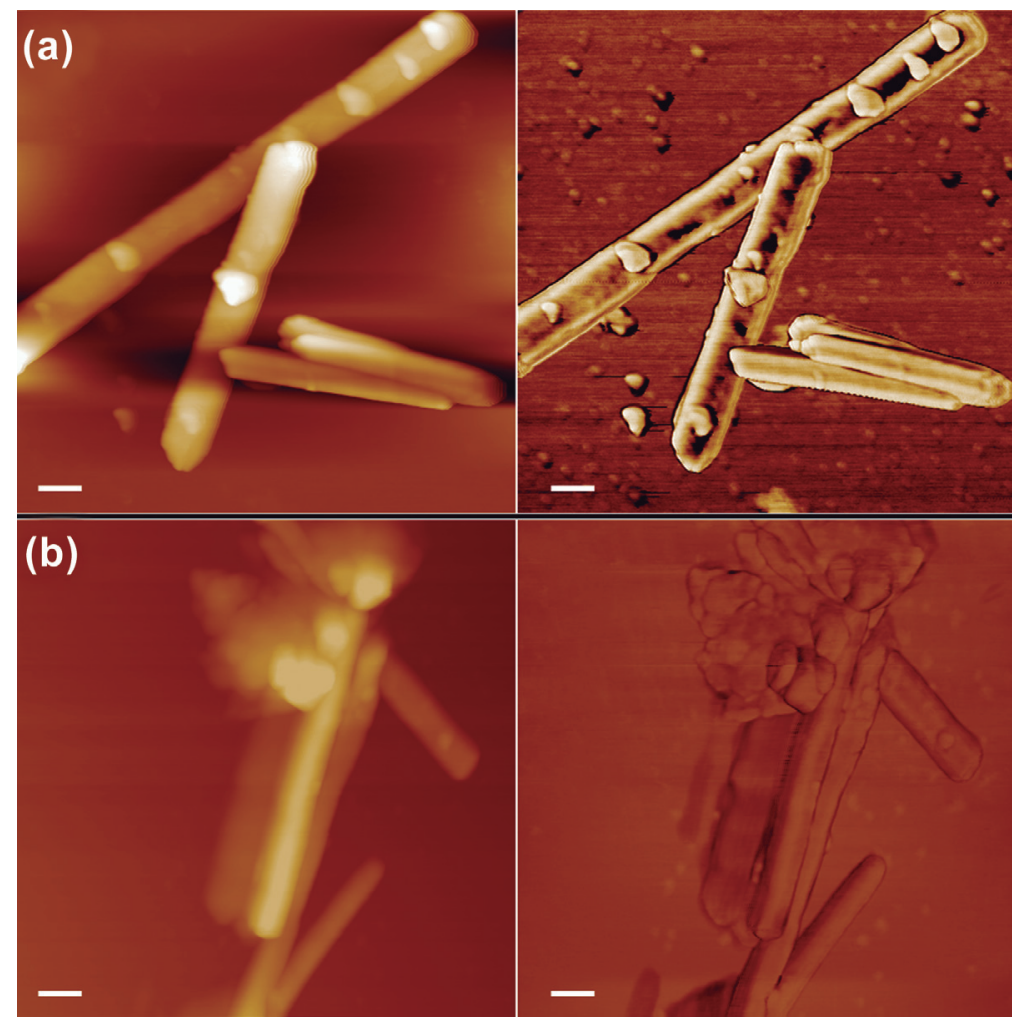

Figure 1- Tapping mode AFM images of enamel crystals on a mica surface, imaged in air. (a) A/J; (b) 129P3/J. Weanling animals had the free access to deionized water and low-F diet until age 12 weeks. Image sizes, $1 \times 1 \mu \mathrm{m} ; \mathrm{bar}=100 \mathrm{~nm}$. (a)=left, height image, $z$ range, $100 \mathrm{~nm}$; right, phase image, $\mathrm{z}$ range, $107.1^{\circ}$. (b)=left, height image, $\mathrm{z}$ range, $120 \mathrm{~nm}$; right, phase image, $z$ range, $16.94^{\circ}$ 
Where $f(x)$ is the roughness curve relative to the center plane, and $L$ is the length of the roughness curve. Therefore, the calculated surface roughness in this case is the mean value of the surface relative to the center plane, and takes into account any changes in the slope of the crystal surface.

\section{Measurement of width}

The measurement of crystal width was done using a Nanoscope III 5.12r3 software. After drawing a line across the crystal, width was automatically displayed. The range of detection of the JV-type scanner was $120 \times 120 \mu \mathrm{m}$ in $\mathrm{x}-\mathrm{y}$ direction and the vertical range was $5 \mu \mathrm{m}$.

\section{Statistical analysis}

The software GraphPad InStat 4 version 3.0 for Windows (GraphPad Software, San Diego, CA, USA) was used. Data were checked for normality and homogeneity using Kolmogorov-Smirnov and Bartlett tests, respectively. Since these criteria were satisfied, data were analyzed by unpaired $t$ test $(p<0.05)$.

\section{RESULTS}

The mean ( $\pm \mathrm{SD}) R_{a}$ of the crystals of $\mathrm{A} / \mathrm{J}$ strain $(0.58 \pm 0.15 \mathrm{~nm})$ was lower than the one found for the $129 \mathrm{P} 3 / \mathrm{J}$ strain $(0.66 \pm 0.21 \mathrm{~nm})$ but the difference did not reach statistical significance $(t=1.187, p=0.247)$. Figure 1 shows typical AFM images of enamel crystals of $A / J$ and $129 \mathrm{P} 3 / \mathrm{J}$ mice. Crystals of the 129P3/J strain (70.42 \pm 6.79 $\mathrm{nm}$ ) were found to be significantly narrower (t with Welch correction $=4.013, p=0.0013$ ) than the same parameter measured for the $A / J$ strain $(90.42 \pm 15.86 \mathrm{~nm})$.

\section{DISCUSSION}

Studies have shown that the A/J and 129P3/J strains present differences in water metabolism ( $A / J$ mice drink higher amounts of water) and fluoride metabolism ( $A / \mathrm{J}$ mice retain less fluoride), regardless $\mathrm{F}$ intake ${ }^{5}$ and key proteins possibly involved with this were recently identified in kidney $^{5}$. Also $A / J$ mice present greater retention of proteins in the maturing enamel, even in the case of no exposure to F9, which leads to lower enamel hardness ${ }^{22}$. Thus, since the main aim of this study was to evaluate differences in the profile of the crystal surfaces of $\mathrm{A} / \mathrm{J}$ and $129 \mathrm{P} 3 / \mathrm{J}$ mice, regardless exposure to $F$, animals were not treated with this ion. In previous studies, $\mathrm{F}$ concentrations were evaluated both in plasma and enamel of $\mathrm{A} / \mathrm{J}$ and $129 \mathrm{P} 3 / \mathrm{J}$ mice exposed to $50 \mathrm{ppm} \mathrm{F}$ in the drinking water or not (control; same condition of the present study). It was observed that, both for plasma ${ }^{5}$ and enamel (unpublished observations), no significant differences were detected among $\mathrm{A} / \mathrm{J}$ and $129 \mathrm{P} 3 / \mathrm{J}$ mice when the animals were not exposed to fluoride. Only when the animals were exposed to $50 \mathrm{ppm}$ fluoride in the drinking water $129 \mathrm{P} 3 / \mathrm{J}$ mice presented significantly higher plasma ${ }^{5}$ and enamel fluoride levels when compared with $A / J$ animals. Thus, changes in enamel crystals profile found in the present study cannot be attributed to alterations in enamel $\mathrm{F}$ concentrations.

This is the first study that compared surface roughness of enamel crystals of mice with different susceptibilities to dental fluorosis. Our results revealed similar values of surface roughness $(R a)$ for the enamel crystals from both the susceptible $(\mathrm{A} / \mathrm{J})$ and the resistant $(129 \mathrm{P} 3 / \mathrm{J})$ mice strains. Thus, the hypothesis that differences in surface crystal roughness could lead to higher retention of matrix proteins and help to explain the different susceptibility of these mice to dental fluorosis could not be confirmed, at least without exposure to $F$. It is possible that if animals are exposed to $F$, surface roughness of the enamel crystals is altered, as has been shown to occur for rats ${ }^{5}$. It would be interesting to see if there are alterations in the pattern of surface roughness of A/J and 129P3/J mice upon treatment with $\mathrm{F}$.

However, an interesting finding was the difference between the strains in the width of the crystals. The crystals width of the "resistant" $129 \mathrm{P} 3 / \mathrm{J}$ strain mice were found to be narrower than the same parameter for the "susceptible" A/J strain, confirming our hypothesis. Such differences had already been shown to occur in bone crystals of mice from these strains. It was observed using powder X-ray diffraction that bone crystals of $A / J$ mice were significantly longer and wider than those of $129 \mathrm{P} 3 / \mathrm{J}$ mice even without exposure to $\mathrm{F}^{16}$. Treatment with $\mathrm{F}$ (100 ppm in the drinking water) did not significantly affect the crystal length but increased the width for both strains, despite the resistant $129 \mathrm{P} 3 / \mathrm{J}$ strain still had narrower bone crystals ${ }^{17}$. The authors proposed that the overall shorter crystal size of $129 \mathrm{P} 3 / \mathrm{J}$ mice suggests that the crystal growth rate of this resistant strain is slower than that of the susceptible strain. This reduced crystal growth rate may be due to stronger mineral-organic interfacial bond that reduces the flux of calcium and phosphate ions to the apatite crystal surface. Stronger mineral-organic interfacial bond has previously been shown to play an important role in bone quality ${ }^{23}$, which may explain the absence of bone mechanical properties alteration in the 129P3/J strain even under high exposure to $\mathrm{F}^{17}$.

In enamel, the mineral-organic interface is equally important to guide crystal growth. The role of amelogenins is very important on this regard 
since these proteins form nanospheres that coat crystal surfaces selectively in the secretory phase of amelogenesis and act as spacer molecules between crystals ${ }^{10,16}$. This coating guides crystals growth. It makes crystals grow in length (c-axis) preventing their lateral fusion ${ }^{16}$. The role of the mineral organicinterface on the mechanism of dental fluorosis development has been emphasized in a new model to explain the development of dental fluorosis ${ }^{3}$. It was proposed that $\mathrm{F}$ accelerates crystal growth and the resulting rapid mineral deposition strongly increases protons production that can no longer be buffered by the available amelogenins. Upon acidic $\mathrm{pH}$, amelogenin nanospheres disaggregate and detach from the crystal surface. Additionally, newly secreted amelogenins are not able to form nanospheres, remaining monomeric. This makes control of preferential crystal growth to be lost, leading to the well-known characteristics of fluorosis ${ }^{3}$.

Based on the above-mentioned observations and on our results, a model to explain the decreased susceptibility to dental fluorosis of the 129P3/] strain could be proposed. The narrower enamel crystals observed for this strain are indicative of slower crystal growth. This would allow an appropriate buffering action of amelogenins that under the adequate $\mathrm{pH}$ would remain attached to the crystal surface, guiding crystal growth. The proposed model would benefit from validation by studies that quantitatively analyze the length and width of the enamel crystals formed by 129P3/] and $A / J$ mice under chronic exposure to $F$. Despite this, it provides new insights into the mechanisms underlying the genetic susceptibility to dental fluorosis. The mechanisms responsible for the differential width of enamel crystals produced by $A / J$ and $129 \mathrm{P} 3 / \mathrm{J}$ mice strains surely deserve investigation. Additional studies should investigate if these differences also occur in humans.

\section{CONCLUSION}

The enamel crystals of the $129 \mathrm{P} 3 / \mathrm{J}$ strain are narrower than $A / J$ mice, and this fact can be an indicative of slower crystal growth, which could contribute to increased susceptibility to dental fluorosis.

\section{AUTHORS' CONTRIBUTIONS}

MARB and BC designed the study. ACB and ALL performed experimental procedures. SRC, JL and $\mathrm{ACJ}$ also assisted in experimental procedures and data interpretation. All authors contributed to writing the manuscript.

\section{CONFLICT OF INTERESTS}

No author had competing or conflicting interests during the duration of this study.

\section{ACKNOWLEDGMENTS}

This study was supported by São Paulo Research Foundation (FAPESP) (2008/03489-2).

\section{REFERENCES}

1- Aoba T, Fejerskov O. Dental fluorosis: chemistry and biology. Crit Rev Oral Biol Med. 2002;13:155-70.

2- Bratthall D, Hänsel-Petersson G, Sundberg H. Reasons for the caries decline: what do the experts believe? Eur J Oral Sci. 1996;104:416-22,23-5,30-2.

3- Bronckers AL, Lyaruu DM, DenBesten PK. The impact of fluoride on ameloblasts and the mechanisms of enamel fluorosis. J Dent Res. 2009;88:877-93.

4- Brookes SJ, Kingswell NJ, Barron MJ, Dixon MJ, Kirkham J. Is the 32-kDa fragment the functional enamelin unit in all species? Eur J Oral Sci. 2011;119(Suppl 1):345-50.

5- Carvalho JG, Leite AL, Yan D, Everett ET, Whitford GM, Buzalaf MA. Influence of genetic background on fluoride metabolism in mice. J Dent Res. 2009;88:1054-8.

6- Chen H, Czajka-Jakubowska A, Spencer NJ, Mansfield JF, Robinson $\mathrm{C}$, Clarkson $\mathrm{BH}$. Effects of systemic fluoride and in vitro fluoride treatment on enamel crystals. J Dent Res. 2006;85:10425.

7- Clark DC. Trends in prevalence of dental fluorosis in North America. Community Dent Oral Epidemiol. 1994;22:148-52.

8- Everett ET, McHenry MA, Reynolds N, Eggertsson H, Sullivan J, Kantmann C, et al. Dental fluorosis: variability among different inbred mouse strains. J Dent Res. 2002;81:794-8.

9- Everett ET, Yan D, Weaver M, Liu L, Foroud T, Martinez-Mier EA. Detection of dental fluorosis-associated quantitative trait Loci on mouse chromosomes 2 and 11. Cells Tissues Organs. 2009;189:212-8.

10- Fincham AG, Moradian-Oldak J, Diekwisch TG, Lyaruu DM, Wright JT, Bringas P Jr, et al. Evidence for amelogenin "nanospheres" as functional components of secretory-stage enamel matrix. J Struct Biol. 1995;115:50-9.

11- Gathercole LJ, Swan AJ, Price G, Dieppe PA. Nanometre-scale surface features of arthropathic microcrystals and their relation to protein adsorption. A study by scanning probe microscopy and wide angle x-ray diffraction. J Mater Sci Mater Med. 1996;7:511-6. 12- Khan A, Moola MH, Cleaton-Jones P. Global trends in dental fluorosis from 1980 to 2000: a systematic review. SADJ. 2005;60:418-21.

13- Kirkham J, Brookes SJ, Shore RC, Bonass WA, Smith DA, Wallwork ML, et al. Atomic force microscopy studies of crystal surface topology during enamel development. Connect Tissue Res. 1998;38:91-100,139-45.

14- Kirkham J, Brookes SJ, Zhang J, Wood SR, Shore RC, Smith DA, et al. Effect of experimental fluorosis on the surface topography of developing enamel crystals. Caries Res. 2001;35:50-6.

15- Mabelya L, van 't Hof MA, König KG, van Palenstein Helderman $\mathrm{WH}$. Comparison of two indices of dental fluorosis in low, moderate and high fluorosis Tanzanian populations. Community Dent Oral Epidemiol. 1994;22:415-20.

16- Moradian-Oldak J. Amelogenins: assembly, processing and control of crystal morphology. Matrix Biol. 2001;20:293-305.

17- Mousny M, Omelon S, Wise L, Everett ET, Dumitriu M, Holmyard $\mathrm{DP}$, et al. Fluoride effects on bone formation and mineralization are influenced by genetics. Bone. 2008;43:1067-74. 
18- Porto IM, Line SR, Laure HJ, Gerlach RF. Comparison of three methods for enamel protein extraction in different developmental phases of rat lower incisors. Eur J Oral Sci. 2006;114(Suppl 1):272-5,285-6,382.

19- Robinson C, Connell S, Kirkham J, Brookes SJ, Shore RC, Smith AM. The effect of fluoride on the developing tooth. Caries Res. 2004;38:268-76.

20- Robinson C, Connell S, Kirkham J, Shore R, Smith A. Dental enamel - a biological ceramic: regular substructures in enamel hydroxyapatite crystals revealed by atomic force microscopy. J Mater Chem. 2004;14:2242-8.

21- Vieira AP, Hancock R, Limeback H, Maia R, Grynpas MD. Is fluoride concentration in dentin and enamel a good indicator of dental fluorosis? J Dent Res. 2004;83:76-80.
22- Vieira AP, Hanocock R, Eggertsson H, Everett ET, Grynpas MD. Tooth quality in dental fluorosis genetic and environmental factors. Calcif Tissue Int. 2005;76:17-25.

23- Walsh WR, Guzelsu N. The role of ions and mineral-organic interfacial bonding on the compressive properties of cortical bone. Biomed Mater Eng. 1993;3:75-84.

24- Whelton HP, Ketley CE, McSweeney F, O'Mullane DM. A review of fluorosis in the European Union: prevalence, risk factors and aesthetic issues. Community Dent Oral Epidemiol. 2004;32(Suppl 1):9-18.

25- Yoder KM, Mabelya L, Robison VA, Dunipace AJ, Brizendine EJ, Stookey GK. Severe dental fluorosis in a Tanzanian population consuming water with negligible fluoride concentration. Community Dent Oral Epidemiol. 1998;26:382-93. 